\title{
ARTICLE
}

\section{Living in Harmony with Nature? A Critical Appraisal of the Rights of Mother Earth in Bolivia}

\author{
Paola Villavicencio Calzadilla* and Louis J. Kotzé***
}

First published online 16 August 2018

\begin{abstract}
Juridical protection of the rights of nature is steadily emerging in several legal systems and in public discourse. Building on a recent publication in Transnational Environmental Law in which we interrogated Ecuador's constitutional experiment with the rights of nature, we critically reflect in this contribution on Bolivia's legal regime providing for the rights of Mother Earth. We do so, first, by sketching the juridical-political context within which these statutes were drafted and adopted, and then by analyzing the relevant constitutional provisions that provide the basis for the laws of Mother Earth. The third part forms the bulk of the discussion and details the background and the most relevant provisions of Bolivian statutes with a view to enabling a deeper critique in Part 4, in which we critically evaluate both the symbolic and the theoretical significance of the statutes as well as concerns related to their practical implementation. Insofar as the rights of nature paradigm has now become a truly global debate and a consideration in transnational comparative legal borrowing practices, our analysis aims to reveal the Bolivian experience, which could be instructive for civil society groups, academics, politicians and legislatures in a transnational setting.
\end{abstract}

Keywords: Anthropocentrism, Ecocentrism, Rights of Mother Earth, Bolivia

\section{INTRODUCTION}

To date, law has been unable to halt the human impacts that are pushing the Earth into a new geological epoch known as the Anthropocene. ${ }^{1}$ In fact, some contend that

* Faculty of Law, North-West University (South Africa) and University of Groningen (The Netherlands). Email: p_villavicencio@hotmail.com.

** Faculty of Law, North-West University (South Africa) and University of Lincoln (United Kingdom). Email: Louis.Kotze@nwu.ac.za.

Research for this article was partly supported by Louis Kotzé’s European Commission Marie Sklodowska Curie project, 'Global Ecological Custodianship: Innovative International Environmental Law for the Anthropocene' (GLEC-LAW), under Grant Agreement No. 751782; this project was completed in May 2018.

1 L. Kotzé (ed.), Environmental Law and Governance for the Anthropocene (Hart, 2017). 
law contributes to, and actively perpetuates the events that are propelling humanity across the planet's ecological boundaries. ${ }^{2}$ In the Anthropocene, Anthropos (the human) takes centre stage above legal hierarchies:

[W] hen it comes to law's relationship with (and mediation of) the lifeworld of the planet and its non-human denizens, it is intensely problematic that the human subject stands at the centre of the juridical order as its only true agent and beneficiary. Law, in other words, is often accused of being resolutely 'anthropocentric', of rotating, as it were, around an anthropos (human/man) for whom all other life systems exist as objects. The same putative 'human centrality' can be said to characterise the discursive trope of the 'Anthropocene'. 3

The deepening socio-ecological crisis of the Anthropocene is characterized by hierarchies imposed by human beings on one another (intra-species hierarchies) and upon non-human entities (inter-species hierarchies). ${ }^{4}$ These hierarchies are intrinsic to anthropocentrism. In the anthropocentric ethic, humans consider themselves the dominant and most important life form; non-human lives are important only insofar as they are useful for maintaining the position of humans at the top of the social hierarchy. ${ }^{5}$

Ecocentrism, on the other hand, is an ethic premised upon nature's intrinsic value, wholly independent of its instrumental value to humanity. ${ }^{6}$ While radical ecocentric counter-narratives have grown over the years in academic discourse, ${ }^{7}$ they have rarely been translated into law. Examples of ecocentric laws are few and far between but they feature mostly in terms of the 'rights of nature' paradigm. The most prominent example is arguably the Ecuadorian Constitution of $2008,{ }^{8}$ the first (and still the only) constitution in the world to entrench enforceable rights of nature. Indigenous peoples in Canada have provided for the rights of nature in their legal systems, ${ }^{9}$ and local laws in some states in the United States have done the same. ${ }^{10}$ A deed of settlement in 2014 granted legal personhood to New Zealand's

2 See, among others, A. Grear, “"Anthropocene, Capitalocene, Chthulucene”: Re-encountering Environmental Law and its "Subject" with Haraway and New Materialism', in Kotzé, ibid., pp. 77-95; T. Stephens, 'Reimagining International Environmental Law in the Anthropocene', in Kotzé, ibid., pp. 31-54; N. Robinson, 'Beyond Sustainability: Environmental Management for the Anthropocene Epoch' (2012) 12(3) Journal of Public Affairs, pp. 181-94; D. Vidas et al., 'International Law for the Anthropocene? Shifting Perspectives in Regulation of the Oceans, Environment and Genetic Resources' (2015) 9 Anthropocene, pp. 1-13.

3 A. Grear, 'Deconstructing Anthropos: A Critical Legal Reflection on "Anthropocentric" Law and Anthropocene "Humanity"' (2015) 26(3) Law and Critique, pp. 225-49, at 225-6.

4 Ibid., p. 230.

$5 \quad$ K. Kortenkamp \& C. Moore, 'Ecocentrism and Anthropocentrism: Moral Reasoning about Ecological Commons Dilemmas' (2001) 21(3) Journal of Environmental Psychology, pp. 261-72, at 262.

6 Ibid.

7 Some of the many include C. Stone, 'Should Trees have Standing? Towards Legal Rights for Natural Objects' (1972) 45 California Law Review, pp. 450-501; K. Bosselmann, Ökologische Grundrechte: Zum Verhältnis zwischen individueller Freibeit und Natur (Nomos Verlagsgesellschaft, 1998); C. Cullinan, Wild Law: A Manifesto for Earth Justice, 2nd edn (Chelsea Green, 2011).

8 Constitution of the Republic of Ecuador, Official Registry No. 449, 20 Oct. 2008.

9 For a comprehensive discussion see J. Borrows, Canada's Indigenous Constitution (University of Toronto Press, 2010).

10 M. Margil, 'Building an International Movement for Rights of Nature', in M. Maloney \& P. Burdon (eds), Wild Law: In Practice (Routledge, 2014), pp. 149-60, at 153-6. 
Whanganui River, ${ }^{11}$ and that country's recent Te Urewera Act 51 of 2014 aims to 'establish and preserve in perpetuity a legal identity and protected status for Te Urewera [an area on the North Island of New Zealand] for its intrinsic worth, its distinctive natural and cultural values, the integrity of those values, and for its national importance'. 12

Another example, and the focus of the present inquiry, comes to us from Bolivia. While its 2009 Constitution recognizes the importance of protecting nature, it does not constitutionally entrench the rights of nature as does its Ecuadorian counterpart. The rights of nature (or Mother Earth) and their protection are instead set out in two statutes: (i) Law 071 of the Rights of Mother Earth of 2010 (Ley 071 de Derechos de la Madre Tierra) (Law of the Rights of Mother Earth), which enumerates specific rights to which Mother Earth is entitled; ${ }^{13}$ and (ii) Framework Law 300 of Mother Earth and Integral Development for Living Well of 2012 (Ley Marco de la Madre Tierra y Desarrollo Integral para Vivir Bien) (Framework Law), ${ }^{14}$ which aims to operationalize the rights of Mother Earth set out in the former law in the context of the so-called integral development for Vivir Bien (living well). Building on a recent publication in Transnational Environmental Law in which we interrogated Ecuador's constitutional experiment with the rights of nature, ${ }^{15}$ in the present article we critically reflect on Bolivia's legal regime providing for the rights of Mother Earth. We start the discussion in Part 2 below by briefly sketching the juridical-political context in which these statutes were drafted and adopted, and then by analyzing the relevant constitutional provisions that provide the basis for these laws of Mother Earth and that bear on environmental protection generally. Part 3 forms the bulk of the discussion and sets out the background and the most relevant provisions of these statutes with a view to enabling a deeper critique in Part 4, where we evaluate both the symbolic and the theoretical significance of the statutes, as well as concerns related to their (admittedly much more problematic) practical implementation.

Our analysis suggests that rights of nature and, in Bolivia's case, rights of Mother Earth have significant potential (especially symbolically, but also otherwise) to frame political, legislative and academic debates on ways to confront the persistent anthropocentrism of law that legitimizes and perpetuates the neoliberal development model the world over. Clearly, however, law also has its limitations and we need to remain realistic about its potential to achieve the desired type of behavioural

11 Whanganui River Deed of Settlement, 5 Aug. 2014, available at: https://www.govt.nz/treaty-settlementdocuments/whanganui-iwi. For a discussion see C.I. Magallanes, 'Reflecting on Cosmology and Environmental Protection: Maori Cultural Rights in Aotearoa New Zealand', in A. Grear \& L. Kotzé (eds), Research Handbook on Human Rights and the Environment (Edward Elgar, 2015), pp. 274-308.

12 Public Act 2014 No. 51, Art. 4, available at: http://www.legislation.govt.nz/act/public/2014/0051/ latest/DLM6183601.html.

13 Law 071 of the Rights of Mother Earth, 21 Dec. 2010; an English version of the law can be found at: http://181.224.152.72/ embajad5/wp-content/uploads/2017/12/rights-of-mother-earth.pdf.

14 Framework Law 300 of Mother Earth and Integral Development for Living Well, 15 Oct. 2012.

15 L. Kotzé \& P. Villavicencio Calzadilla, 'Somewhere between Rhetoric and Reality: Environmental Constitutionalism and the Rights of Nature in Ecuador' (2017) 6(3) Transnational Environmental Law, pp. 401-33. 
transformation and to effectively counter deeply vested corporate-driven neoliberal and political economic interests. It is further evident that it remains immensely difficult to implement rights of nature in practice and to balance them with development priorities, especially in a developing country context such as Bolivia where poverty is rife and ecologically destructive extractivism is often the easiest and most lucrative way to fill state coffers, regardless of what the constitution and the law say. Yet, while there seem to be no easy answers to such profound contradictions and complexities that overshadow the idealistic promise and potential of juridically innovative ways to safeguard Earth system integrity, the rights of nature debate and its practical manifestation in legal systems such as that of Bolivia provide considerable opportunities to begin with a much needed re-imagination of law and its ability to protect nature.

\section{THE CONSTITUTIONAL CONTEXT}

At the dawn of the $21^{\text {st }}$ century, Bolivia went through a crisis of statehood, marked by a series of protests by various social groups and indigenous organizations that demanded the reconstruction of the state and the reform of its laws and politics. ${ }^{16}$ This uprising culminated in two watershed events, both inspired by a desire to defend the country's natural resources: the so-called Water War in 2000 and the October War (or Gas War) in 2003. ${ }^{17}$ Both conflicts revealed popular dissatisfaction with the neoliberal development model that prevailed in Bolivia at the time.

As a result, in December 2005 Bolivians elected their first indigenous president, Evo Morales, a prominent leader of coca-growing peasants. In response to popular demand, the newly elected president inaugurated a Constitutional Assembly in August 2006. The Assembly would embark on drafting a new Constitution, ${ }^{18}$ which ultimately intended to bring about the wholesale transformation of the Bolivian state and society based on the recognition of every Bolivian as a vital component of a unified country. The call for the establishment of a Constitutional Assembly essentially arose from a coalition of the largest indigenous and peasant organizations in Bolivia, which in 2004 formed the so-called Unity Pact (Pacto de Unidad) with the objective of ensuring their full participation in the constitutional drafting process and in the future governance of the country. ${ }^{19}$

16 For a recent discussion of this process see F. Viduarre Belmonte, 'Right to Justice and Diversity of the Indigenous Peoples of Bolivia', in H. Devere, K. Te Maihāroa \& J. Synott (eds), Peacebuilding and the Rights of Indigenous Peoples: Experiences and Strategies for the 21 ${ }^{\text {st }}$ Century (Springer, 2017), pp. 77-85.

17 See, among others, B. Kohl \& L. Farthing, Impasse in Bolivia: Neoliberal Hegemony and Popular Resistance (Zed Books, 2006), pp. 149-78; P. Villavicencio Calzadilla, 'El proceso constituyente boliviano en el siglo XXI: Corolario del movimiento político indígena', in A. Pigrau (ed.), Pueblos indígenas, diversidad cultural y justicia ambiental: Un estudio de las nuevas constituciones de Ecuador y Bolivia (Tirant lo Blanch, 2013), pp. 661-721.

18 For information about the constitutional history of Bolivia see: http://www.constitutionnet.org/country/ constitutional-history-bolivia.

19 The Unity Pact is a coalition of Bolivia's five largest peasant and indigenous organizations. It was closely allied with the Bolivian government from 2005, but lack of progress and recent events, such as the conflict surrounding the Isiboro Sécure National Park and Indigenous Territory (Territorio 
After a long and complex process, the Assembly prepared a draft constitution that was approved by the National Congress and accepted following a constitutional referendum in January 2009. With an approval rate among voters of $61.43 \%$, the new Constitution came into force in February $2009 .{ }^{20}$ The Constitution abolished the existing republic and in its place created a 'plurinational' state, which recognized the 36 indigenous nations that constitute part of the country's socio-political fabric. ${ }^{21}$ Thus, the Constitution has been described as 'among the most radical [constitutions] in the world regarding the incorporation of international human rights criteria and the recognition of specific indigenous rights'. ${ }^{22}$ Because the Assembly involved broad participation by indigenous people, who had previously been excluded from the state's decision-making processes, the Constitution was viewed as the culmination of more than 500 years of struggle for liberation by indigenous people against colonial and republican rule and oppression. The Preamble to the Constitution aptly proclaims:

We, the Bolivian people, of plural composition, from the depths of history, inspired by the struggles of the past, by the anti-colonial indigenous uprising, and in independence, by the popular struggles of liberation, by the indigenous, social and labor marches, by the water and October wars, by the struggles for land and territory, construct a new State in memory of our martyrs.

The Bolivian Constitution, like its Ecuadorian counterpart, ${ }^{23}$ constitutionalized the protection of nature, termed Mother Earth or Pachamama, which is described in the Preamble as the common home where all forms of life have always coexisted harmoniously:

In ancient times mountains arose, rivers moved, and lakes were formed. Our Amazonia, our swamps, our highlands, and our plains and valleys were covered with greenery and flowers. We populated this sacred Mother Earth with different faces, and since that time we have understood the plurality that exists in all things and in our diversity as human beings and cultures. Thus, our peoples were formed, and we never knew racism until we were subjected to it during the terrible times of colonialism.

The Bolivian Constitution does not formally recognize nature as the bearer of rights as does Ecuador, but it does provide for an environmental right: '[E]veryone has the right to a healthy, protected, and balanced environment. The exercise of this right must be granted to individuals and collectives of present and future generations, as well as to other living things, so they may develop in a normal and permanent way. ${ }^{24}$ The

Indigena y Parque Nacional Isiboro Secure (TIPNIS)) (see 4.5 below), caused the severing of relations between the government and some members of the Pact.

20 F. Gamboa, Dilemas y conflictos sobre la Constitución en Bolivia: Historia Política de la Asamblea Constituyente (Konrad Adenauer Foundation, 2009).

21 Constitution of the Plurinational State of Bolivia, 2009, Art. 1, available at: https://www.constituteproject.org/constitution/Bolivia_2009?lang=en.

22 R. Lalander, 'Ethnic Rights and the Dilemma of Extractive Development in Plurinational Bolivia' (2016) 21(4) The International Journal of Human Rights, pp. 465-81, at 465.

23 N. 8 above. For a discussion see Margil, n. 10 above; S. Borràs, 'New Transitions from Human Rights to the Environment to the Rights of Nature' (2016) 5(1) Transnational Environmental Law, pp. 113-43; Kotzé \& Villavicencio Calzadilla, n. 15 above. 
Constitution also recognizes that 'any person, in his own right or on behalf of a collective, is authorized to take legal action in defense of environmental rights, without prejudice to the obligation of public institutions to act on their own in the face of attacks on the environment'. ${ }^{25}$ While this environmental right is formulated in generic terms common to many constitutions elsewhere, ${ }^{26}$ it innovatively extends its protection to 'other living things', ${ }^{27}$ implying that human beings should act as caretakers to exercise the right on behalf of Mother Earth. ${ }^{28}$ In a similar vein, while not explicitly entrenching the rights of Mother Earth, the Constitution does seem to keep the door open, if not to the future constitutionalization of such rights, then at least to their ex post recognition through statutory regulation, as is the case presently. Article 13(II) says in this respect: 'The rights declared in this Constitution shall not be understood to deny other rights that are not enumerated'; they are therefore broadly accommodative of any subsequent normative arrangements that seek to protect the rights of Mother Earth.

Significantly, the Preamble further provides: 'We found Bolivia anew, fulfilling the mandate of our people, with the strength of our Pachamama and with gratefulness to God'. What these words suggest, in addition to the commitment of Bolivians to a new state, is, in the words of Colón-Ríos, that the constitutional protection of Mother Earth is justified as:

A constitutional form that - just as the right to vote or the freedom of assembly - will tend to promote a state of things in which different forms of democratic decision making, including the exercise of constituent power, will be possible ... Without the strength given by nature, which always forms an integral part of the many meanings that can be attributed to the concept of Pachamama ... it would not have been possible for the Bolivian people to adopt a new constitution. The continuing existence of nature as we know it ... is a necessary precondition for the future exercise of constituent power as well as any form of political action. ${ }^{29}$

24 Art. 33.

25 Art. 34. The Constitution also introduces (Arts 135-136) a new constitutional remedy, termed 'popular action' (acción popular), as a mechanism to protect and defend collective rights and interests, including those embraced by the environmental right.

26 For a detailed discussion of constitutional environmental rights see J. May \& E. Daly, Global Environmental Constitutionalism (Cambridge University Press, 2015); D. Boyd, The Environmental Rights Revolution: A Global Study of Constitutions, Human Rights and the Environment (UBC Press, 2011); C. Jeffords \& J. Gellers, 'Constitutionalizing Environmental Rights: A Practical Guide' (2017) 9(1) Journal of Human Rights Practice, pp. 136-45.

27 While it is not the primary focus of this article, it is worth noting in passing that the Bolivian judiciary has recognized: (i) the environmental right as a diffuse right held by indeterminate groups of individuals linked to factual circumstances; and (ii) the popular action as a constitutional remedy can be filed by any person or group of individuals to enforce the environmental right: see, e.g., Paniagua et al. v. Gobernador del Dpto. de Santa Cruz et al, Plurinational Constitutional Court, Judgment 1082/2013-L, 30 Aug. 2013, available at: https://buscador.tcpbolivia.bo/_buscador/(S(eiujcgptjb0cn4cl4apysytf))/ WfrFechaResolucion1.aspx. While this is encouraging, further jurisprudential development is required in order to determine the importance, content, and scope of the environmental right, including, e.g., its reference to 'other living things' and their right to 'develop in a normal and permanent way'.

28 Rights usually have corresponding duties. According to Art. 108(16) of the Constitution, the environmental right creates the duty on every Bolivian to protect and defend a suitable environment for the development of living beings.

29 J. Colón-Ríos, 'Constituent Power, the Rights of Nature, and Universal Jurisdiction' (2014) 60(1) McGill Law Journal, pp. 127-72, at 150. 
Therefore, even though the Bolivian Constitution does not constitutionalize the rights of Mother Earth, it recognizes at the highest constitutional level the importance of ecological integrity, which enables people to create a new future for themselves through a new constitutional framework: without the integrity of nature, a new constitutional democracy will be impossible. It might even be said that the Constitution recognizes ecological integrity as the basis of the Bolivian constitutional state, a position that mirrors the German theoretical notion of the ecological constitutional state (ökologische Verfassungsstaat). ${ }^{30}$

The Constitution also recognizes ancestral principles, especially those that underpin the Aymara culture, such as Vivir Bien or Suma Qamaña (living well), which has been adopted as one of the ethical and structural principles of the state. ${ }^{31}$ As with the related principle of Buen Vivir or Sumak Kawsay in the Ecuadorian Constitution, Vivir Bien is a concept that is deeply rooted in indigenous traditions, and which affirms the need to live in harmony with Mother Earth and in equilibrium with all forms of life. ${ }^{32}$ Vivir Bien also provides the discursive context for discussions about natural resources, the creation of a plurinational state, cultural decolonization, and the rights of nature. ${ }^{33}$ The inclusion of this principle in the Constitution is especially relevant because indigenous people are often considered to be the 'guardians of nature', 34 and because the harmonious coexistence of human beings and nature in a distinctly non-hierarchical setting has been part of the indigenous social fabric of Bolivia since time immemorial. Vivir Bien signifies a radical opposition to the neoliberal consumerist, growth-without-limits paradigm, which for many years has promoted the exploitation of natural resources and of vulnerable people, including especially women, children and indigenous peoples in Bolivia. It 'challenges the anthropocentric approach to civilization based only on the power of markets and financial resources, in which money is what gives life to everything and development is a means without end'. ${ }^{35}$ That Vivir Bien actively militates

30 The ecological constitutional state, says Steinberg, essentially should aim to protect natural living conditions in their own right as an end in itself, and as a means to an end to the extent that the contemporary constitutional state and the social order it seeks to maintain is entirely dependent on a mutually supportive, intact, and harmonious Earth system: R. Steinberg, Der ökologische Verfassungsstaat (Suhrkamp, 1998), p. 45.

31 Art. 8 of the Bolivian Constitution identifies the ethical principles that underpin the state as: 'ama qhilla, ama llulla, ama suwa [do not be lazy, do not be a liar or a thief], suma qamaña [live well], $\tilde{n}$ andereko [live harmoniously], teko kavi [the good life], ivi maraei [a land without evil] and qhapaj ñan [the noble path of life]'.

32 The Constitution does not provide a clear definition of Vivir Bien. The only legislation that provides a detailed description of the meaning and scope of this concept is the Framework Law (n. 14 above), which is discussed in Part 3 of this article.

33 E. Gudynas, 'Development Alternatives in Bolivia: The Impulse, the Resistance, and the Restoration' (2013) 46(1) NACLA Report on the Americas, pp. 22-6, at 25. In addition to such (mostly indigenous) spiritual foundations, the rights of nature paradigm is also being developed in the context of more Western oriented non-spiritual contexts, possibly exemplified most clearly in this instance by the work of Christopher Stone: see Stone, n. 7 above.

34 See, e.g., United Nations (UN) Secretary-General, 'Statements and Messages: Permanent Forum Can Play Dynamic Role in Changing Deplorable Situation of Indigenous People, Secretary-General Says at Opening of Session', 16 May 2011, available at: http:/www.un.org/News/Press/docs/2011/sgsm13575.

35 Plurinational State of Bolivia, 'Living Well in Balance and Harmony with Mother Earth: A Proposal for Establishing a New Global Relationship between Human Beings and Mother Earth', Dec. 2014, p. 21. 
against neoliberal oppression is clear from the Preamble to the Constitution, in which Bolivians state: 'We have left the colonial, republican and neo-liberal State in the past'.

Such a fierce rejection is not surprising if one considers that the prevailing economic development model in Bolivia, based on the exploitation of natural resources and the domination of nature as it is in many other countries across the world, has had socio-ecological impacts, especially on indigenous peoples. ${ }^{36}$ In response to ever-increasing environmental degradation, indigenous organizations during the constitutional drafting process re-imagined the protection of Mother Earth in a manner that transcends the trite anthropocentric orientation of the previous legal system. Collectively these 'cosmovisions' presented 'alternatives to [exploitative neoliberal] development', as Gudynas says:

The notable initial changes and the debates over the rights of Mother Earth and vivir bien - expanded conceptions and feelings of a good life, both in communitarian and ecological senses - [and] reinforced the idea that substantial alternatives to Western conceptions of development were in the offing. ${ }^{37}$

Not to be confused with 'development alternatives', which often merely amount to the same but differently expressed neoliberal modes of exploitation, these 'alternatives to development' seek to go beyond Western modernity. As we shall see in Part 3, such 'alternatives', at least on paper, include radical juridical constructions intended to transform deeply embedded exploitative and oppressive practices. The extent to which they succeed is a matter we take up in Part 4.

\section{THE STATUTORY LAWS ON THE RIGHTS OF NATURE}

The world's first Law of the Rights of Mother Earth, adopted in December 2010, arose out of the Constitution's requirement for a new, integrated form of development, designed in harmony with nature and oriented towards Vivir Bien. ${ }^{38}$ In October 2012, the Plurinational Legislative Assembly adopted the Framework Law, ${ }^{39}$ which, as its name suggests, serves as a normative umbrella under which other sectoral laws must operate. ${ }^{40}$ Although the Framework Law does not have supreme constitutional force, it is of preferential application to related laws dealing with natural resources and extraction, which must correspond with and are subject to the provisions of the Framework Law. ${ }^{41}$

Both laws emerged in part from a single negotiation process between the Bolivian government and the indigenous organizations of the Unity Pact.

36 Over the past 30 years the extractive industries in Bolivia, having been developed in protected natural areas and indigenous territories, have contributed to the degradation of one third of the national territory: Liga de Defensa del Medio Ambiente (LIDEMA), Estado ambiental de Bolivia (LIDEMA, 2013).

37 Gudynas, n. 33 above, p. 22.

38 Law 071, n. 13 above.

39 Framework Law 300, n. 14 above.

40 Ibid., Art. 2 and second additional provision.

41 Lalander, n. 22 above, p. 472. 
The framework regulation was part of a complete restructuring of the country's legal system that accompanied the adoption of the new Constitution. Having assumed responsibility for representing the interests of Mother Earth during the constitutional drafting process, the Unity Pact also assumed the mandate of formulating a draft law based upon the proceedings of the World People's Conference on Climate Change and the Rights of Mother Earth, which had been held in Cochabamba (Bolivia) in April 2010. ${ }^{42}$ The Pact derived its mandate from the agreement of the conference participants to build a global movement in defence of all forms of life and of Mother Earth in particular, which also resulted in the widely celebrated global adoption of the Universal Declaration of the Rights of Mother Earth. ${ }^{43}$ The Unity Pact and representative members of the Legislative Assembly negotiated and eventually agreed a final version of a draft law on Mother Earth (Unity Pact Draft Law), which sought to comprehensively represent the interests of both the indigenous organizations and the government. $^{44}$

Importantly, the Unity Pact Draft Law maintained a strong ecocentric orientation. For example, its Preamble stated:

This law guides human beings ... to defend, protect, mitigate and restore Mother Earth ..., [and defends] the life and the beings living in the common home of Mother Earth. This law reorientates human beings ... to meet again with Mother Earth, returning to her in a complementary way and creating a reciprocal relationship between them and all living beings integrating her. Human beings ... are part of nature. In this sense, they are not the centre of Mother Earth ... as being part [of her], they must ... [coexist] in a complementary and reciprocal way, contributing to the harmonious coexistence in order to achieve the Vivir Bien. ${ }^{45}$

The Law was aimed at defending and protecting Mother Earth while guiding legislative developments at all levels of the state (national, departmental and municipal). ${ }^{46}$ It was also a reaction to growing concerns over perceived policies of discrimination and exclusion that were being implemented by the Morales government against indigenous people in order to promote the expansion of the extractive industry. ${ }^{47}$

42 This summit, which was inspired by the culture of the Andean indigenous peoples, was called by the Bolivian government in response to the failure of the 2009 Copenhagen Summit on Climate Change.

43 Available at: https://pwccc.wordpress.com/support. The adoption of this Declaration had already been mooted in the VII Summit of the Bolivarian Alliance for the Peoples of Our America: Peoples' Trade Treaty (La Alianza Bolivariana para los Pueblos de Nuestra América: Tratado de Comercio de los Pueblos ALBA-TCP), held in Bolivia in Oct. 2009. In that summit, the member states acknowledged that in order to guarantee human rights, recognition and the protection of the rights of Mother Earth are critical: I. Colon (coord.), La ALBA: el horizonte latinoamericano del Siglo XXI (FEDAEPS, 2013), pp. 171-3 and 175-84.

44 Pacto de Unidad, 'Anteproyecto de Ley de la Madre Tierra', 7 Nov. 2010, available at: http://www.somossur.net/crisis-del-capitalismo/todo-sobre-el-cambio-climatico/540-ley-de-la-madretierra.html.

45 As no English version is available, all references to the Unity Pact Draft Law are the authors' translations.

46 Pacto de Unidad, n. 44 above, Art. 1.

47 D. Hindery, From Enron to Evo Pipeline Politics, Global Environmentalism, and Indigenous Rights in Bolivia (The University of Arizona Press, 2013), p. 217. 
The Unity Pact Draft Law went well beyond environmental protection. Most notably, it recognized Mother Earth as a bearer of certain rights, and it set out the duties of both state and society in this regard. ${ }^{48}$ It established core binding principles such as the need to maintain a harmonious relationship with Mother Earth, the need to respect and defend the rights of Mother Earth, that there was to be no commercialization of living systems or their processes, and the in dubio pro natura principle, which provides that whenever there is doubt as to the consequences of an action on the rights of Mother Earth, the relevant authority must always act in favour of Mother Earth. ${ }^{49}$ Moreover, by promoting a new ecologically oriented economic model, it confirmed that the Bolivian economy must operate within the limits of the Earth. ${ }^{50}$ The Draft Law also required the government to establish the necessary policies to achieve a shift from fossil fuels to clean and renewable resources. ${ }^{51}$ As Hindery points out, the Law, if adopted, would have prevented the approval of the many future extractive projects planned by the Bolivian government. ${ }^{52}$

The Unity Pact Draft Law, however, was neither approved nor adopted. Despite the fact that the Unity Pact and the members of the Legislative Assembly had signed an agreement committing themselves to retain and to defend this law, ${ }^{53}$ it faltered because of the Bolivian government's concerns that, had it been passed, it would have bolstered opposition to the development agenda which, at the time, included the construction of a highway through a national park and indigenous territory, ${ }^{54}$ and the continuation and expansion of a lucrative extractivist agenda. ${ }^{55}$

The government instead proceeded with a different, two-pronged, strategy. Firstly, on 7 December 2010, the Plurinational Legislative Assembly approved the Law of the Rights of Mother Earth, which included only an excerpt from the Unity Pact Draft Law. Members of the Unity Pact indicated that the swift passage of the Law was a thinly disguised attempt to bolster the Bolivian government's protagonist image during the Climate Change Conference held in Cancún (Mexico) in late 2010. ${ }^{56}$ The government, however, indicated that the law paved the way for a more comprehensive and definitive framework law aimed at operationalizing its content. ${ }^{57}$

48 Pacto de Unidad, n. 44 above, Preamble and Arts 5, 7, 8, 9 and 12.

49 Ibid., Art. 3.

50 Ibid., Art. 13.II.1.

51 Ibid., Arts 8.8 and 25.8.a.

52 Hindery, n. 47 above, p. 217.

53 Pacto de Unidad, n. 44 above.

54 See Part 4 below.

55 R. Prada Alcoreza, 'Matricidio del Estado patriarcal', 25 July 2013, available at: https://systemicalternatives.org/2014/06/19/matricidio-del-estado-patriarcal.

56 Agencia de Noticias Fides, 'Conamaq: Evo sólo busca protagonismo con la Ley Madre Tierra en Cancún’, 9 Dec. 2010, available at: http://www.noticiasfides.com/nacional/politica/conamaq-evo-solobusca-protagonismo-con-ley-madre-tierra-en-cancun-295856.

57 La Razón, 'Sancionan ley de la Madre Tierra: Evo la presentará en Cancún', 8 Dec. 2010, available at: http://www.la-razon.com/sociedad/Sancionan-Madre-Tierra-Evo-Cancun_0_1300070006.html. For a related discussion in the Brazilian context, see E. Fernandes, 'Law, Politics and Environmental Protection in Brazil' (1992) 4(1) Journal of Environmental Law, pp. 41-56, at 54; R. O'Gorman, 'Environmental Constitutionalism: A Comparative Study' (2017) 6(3) Transnational Environmental Law, pp 435-62, at 459-60. 
As a second step, two years later in October 2012, the Legislative Assembly adopted the Framework Law, which some considered a watered-down version of the Unity Pact Draft Law. The adoption of the Law was opposed by members of the Unity Pact, as it had been predominantly elaborated by pro-government Assembly members and other government officials without consideration of the Unity Pact Draft Law. ${ }^{58}$ There were also procedural concerns related to the drafting process, with some indicating that the Assembly's debate of the Framework Law had not complied with the prescribed timelines. ${ }^{59}$ As several grassroots groups and indigenous organizations that contributed to the Unity Pact Draft Law in the first place had been deliberately excluded by government officials from the drafting process of the Framework Law, ${ }^{60}$ they eventually decided to withdraw from the legislative process, citing irreconcilable differences regarding its content. ${ }^{61}$ Only a few indigenous organizations that had broken away from the Unity Pact remained involved, which meant that not all of the 36 indigenous nations of Bolivia were fully represented during the drafting process. ${ }^{62}$

The legislative process eventually resulted in the adoption of two laws currently in force: the Law of the Rights of Mother Earth and the Framework Law. These two laws seem to complement each other, as they include ecocentric aspirations related to the recognition and protection of the rights of Mother Earth in a context of integral development for Vivir Bien. However, several powerful pro-development provisions are included in these laws, which potentially counter-balance the ecocentric provisions, as we shall see below.

\subsection{The Law of the Rights of Mother Earth}

The Constitution of Bolivia does not expressly grant rights to nature. It does provide a basis for such recognition through the constitutionalization of a right to the environment, its references to other non-human living beings, as well as recognition of the indigenous cosmovision of Vivir Bien. To this end, the 2010 Law of the Rights of Mother Earth, the world's first statutory law granting rights to nature, builds on this constitutional foundation by recognizing the rights of Mother Earth as well as the obligations and duties of the state and society to ensure respect for those rights. ${ }^{63}$

What is immediately apparent from the title of the law is its reference to 'Mother Earth' rather than merely to 'nature'. This choice of words signifies a profound idea nestled in indigenous cultures - that the Earth is the source of life, the mother of everything and everyone. ${ }^{64}$ In addition to giving life, mothers nurture, care, feed,

58 Servendi, 'Bolivia: Cuestionan Ley de la Madre Tierra no consensuada con organizaciones indígenas', 17 Oct. 2012, available at: https://www.servindi.org/actualidad/74784.

59 Carta de la Brigada Indigena de la Asamblea Legislativa Plurinacional de Bolivia a la Presidenta de la Cámara de Diputados, 24 Aug. 2012, available at: https://www.bolpress.com/?Cod=2012082404.

60 Ibid.

61 Servendi, n. 58 above.

62 Ibid.

63 Law 071, n. 13 above, Art. 1.

64 E.R. Zaffaroni, 'La Pachamama y el humano', in A. Acosta \& E. Matínez (eds), La naturaleza con derechos: de la filosofía a la política (Abya Yala, 2011), pp. 25-137, at 112-3. 
console and raise those dependent on them. Mother Earth, a distinctly feminine entity, does the same. She is not a destructive and dominating masculine entity who 'separates' herself from those she supports, and she does not embody the paternal and possessive characteristics attributed to 'masculine' anthropocentrism more generally and to Anthropos specifically. ${ }^{65}$ In the preambular words of the Constitution itself, Mother Earth, far from a weak and subjugated female, is celebrated as a sacred and powerful maternal entity: 'with the strength of our Pachamama', declares the text, the Bolivian people have 'found Bolivia anew'.

As to the specific provisions of the Law, the rights of Mother Earth are underpinned by a set of legally binding principles, which, at least in terms of content and objectives, resemble other legal and quasi-legal texts such as the World Charter for Nature of $1982^{66}$ and the Earth Charter. ${ }^{67}$ These principles are radical insofar as most of them attempt to go well beyond the principles of anthropocentric sustainable development, such as polluter pays, prevention, and precaution. ${ }^{68}$ The first principle is titled 'harmony' and requires that 'human activities, within the framework of plurality and diversity, must achieve a dynamic balance with the cycles and processes inherent in Mother Earth'. The second principle, however, then seems to prioritize human interests by stating that 'the interests of society, within the framework of the rights of Mother Earth, prevail in all human activities and over any acquired right'. The potential for ethical tensions and normative conflict between this principle and the other ecocentric provisions of the Law is evident and somewhat surprising if one accepts that the main purpose of the Law is to establish and protect the rights of Mother Earth, and thus to prioritize these rights. Such normative tensions also foreshadow challenges in implementation, a matter to which we return below.

The third principle places a duty of protective stewardship on the state and on all people by proclaiming:

The state, at its various levels, and society, in harmony with the common interest, must ensure the necessary conditions in order that the diverse living systems of Mother Earth can absorb damage, adapt to shocks, and regenerate without significantly altering their structural and functional characteristics, recognizing that living systems are limited in their ability to regenerate, and that humans are limited in their ability to undo their actions.

While this affirms the principle of ecological integrity, which for years some have sought to emplace in legal structures the world over, ${ }^{69}$ also of significance is its recognition of a systems approach to ecological governance, which is broadly in line with contemporary paradigms that advocate holism and integration. ${ }^{70}$ In addition, the

65 Cf. Grear, n. 3 above, p. 232.

66 UN General Assembly (GA) Resolution 37/7, 'World Charter for Nature' (28 Oct. 1982), UN Doc No. $\mathrm{A} / \mathrm{RES} / 37 / 7$.

67 K. Bosselmann \& R. Engel (eds), The Earth Charter: A Framework for Global Governance (KIT Publishers, 2011).

68 Law 071, n. 13 above, Art. 2.

69 See, e.g., D. Pimentel, L. Westra \& R. Noss (eds), Ecological Integrity: Integrating Environment, Conservation, and Health (Island Press, 2000).

70 F. Biermann, Earth System Governance: World Politics in the Anthropocene (The MIT Press, 2014). 
principle of defence and respect for the rights of Mother Earth provides that ' $\mathrm{t}] \mathrm{he}$ State and any individual or collective person must respect, protect and guarantee the rights of Mother Earth for the well-being of current and future generations'. The principle of 'no commercialism' requires that '[n] either living systems nor processes that sustain them may be commercialized, nor serve anyone's private property'. This probably ranks as one of the most controversial but toothless principles in the Law, to the extent that mineral and gas exploitation continues to flourish in Bolivia, as we shall see below.

Finally, the principle of multiculturalism, which recognizes the important contributions by indigenous people in shaping the law and environmental governance more generally, states:

The exercise of the rights of Mother Earth requires the recognition, recovery, respect, protection, and dialogue of the diversity of feelings, values, knowledge, skills, practices, transcendence, transformation, science, technology and standards of all the cultures of the world who seek to live in harmony with nature.

Mother Earth is regarded by the law as a dynamic living system comprising an indivisible community of all living systems and organisms, which are interrelated, interdependent, and complementary, and which share a common destiny. ${ }^{71}$ All human communities and natural entities collectively interact as a functional unit under the influence of climatic, physiographic, and geological factors. ${ }^{72}$ At least on paper, these principles represent an attempt to overcome the Cartesian dualism which disassociates people from Mother Earth.

Rights are worthless if they are not enforceable. To this end, Article 5 of the Law clarifies the juridical status of Mother Earth in the following terms:

Mother Earth takes on the character of collective public interest. Mother Earth and all her components, including human communities, are entitled to all the inherent rights recognized in this Law. The exercise of the rights of Mother Earth will take into account the specificities and particularities of her various components. The rights under this Law shall not limit the existence of other rights of Mother Earth.

The exercise of the rights in the Law is entrusted to 'all Bolivians', who are part of 'the community of beings that form Mother Earth'. ${ }^{73}$ The wording implies that Bolivians should not act as disinterested outsiders on behalf of Mother Earth, but rather in their own and Mother Earth's collective interests, to the extent that 'all Bolivians' are part of the 'community of beings comprising Mother Earth'. 74

Closely related to the issue of enforcement are statutory measures supporting the 'defence of Mother Earth'. The Law provides for the establishment of the Office of Mother Earth or the Mother Earth Ombudsman (Defensoria de la Madre Tierra), a counterpart to the Office of the Human Rights Ombudsman (Defensoría del Pueblo), ${ }^{75}$ in order to ensure the promotion and fulfilment of the

71 Law 071, n. 13 above, Art. 3.

72 Ibid., Art. 4.

73 Ibid., Art. 6.

74 These enforcement provisions are potentially further strengthened by the Constitution's provision of a popular action: see n. 25 above. 
rights of Mother Earth. Its structure and organization were left for future legislation and, to date, the Office has not been created.

Article 7 sets out in some detail several specific rights of Mother Earth. These rights are arguably the foundation of the Law and they are worth quoting in full:

1. To life: The right to maintain the integrity of living systems and natural processes that sustain them, and capacities and conditions for regeneration.

2. To the diversity of life: It is the right to preservation of differentiation and variety of beings that make up Mother Earth, without being genetically altered or structurally modified in an artificial way, so that their existence, functioning or future potential would be threatened.

3. To water: The right to preserve the functionality of the water cycle, its existence in the quantity and quality needed to sustain living systems, and its protection from pollution for the reproduction of the life of Mother Earth and all her components.

4. To clean air: The right to preserve the quality and composition of air for sustaining living systems and its protection from pollution, for the reproduction of the life of Mother Earth and all her components.

5. To equilibrium: The right to maintenance or restoration of the interrelationship, interdependence, complementarity and functionality of the components of Mother Earth in a balanced way for the continuation of their cycles and reproduction of their vital processes.

6. To restoration: The right to timely and effective restoration of living systems affected by human activities, directly or indirectly.

7. To pollution-free living: The right to the preservation of any of Mother Earth's components from contamination, as well as toxic and radioactive waste generated by human activities.

These rights are highly aspirational and cover the foundations of Earth system integrity. Moreover, in the exercise of the rights, Article 6 sets out a clear presumption in favour of the rights of Mother Earth: '[T]he exercise of individual rights is limited by the exercise of collective rights in the living systems of Mother Earth. Any conflict of rights must be resolved in ways that do not irreversibly affect the functionality of living systems'. ${ }^{76}$

Rights automatically create duties, whether positive, negative or both. Article 108 of the Constitution provides the constitutional basis for statutory duties in relation to the rights of Mother Earth, and directs 'all Bolivians' to 'safeguard, defend and protect the natural, economic, and cultural patrimony of Bolivia', to 'protect and defend the natural resources, and to contribute to their sustainable use in order to preserve the rights of future generations', and to 'protect and defend an environment suitable for the development of living beings'. Premised on this foundation, the Law

75 Law 071, n. 13 above, Art. 10.

76 Ibid., Art. 6. 
of the Rights of Mother Earth in Article 8 enunciates a number of obligations that rest on the state 'at all levels and geographical areas and across all authorities and institutions'. ${ }^{77}$ The state has, among others, the following duties:

- to develop public policies and actions of prevention, early warning, protection, and precaution;

- to develop balanced forms of production and patterns of consumption, while safeguarding the regenerative capacity and integrity of the cycles, processes and vital balance of Mother Earth;

- to develop policies to protect Mother Earth from the multinational and international scope of exploitation of its components, from the commodification of living systems or the processes that support them, and from the structural causes and effects of global climate change; and

- to develop policies to ensure the long-term energy sovereignty and gradual incorporation of clean and renewable alternative sources into the energy matrix.

Natural persons and public and private legal entities also have legal duties, which include:

- upholding and respecting the rights of Mother Earth;

- promoting harmony with Mother Earth in all areas of her relationship with other human communities and the rest of nature in living systems;

- participating actively, individually or collectively in generating proposals designed to respect and defend the rights of Mother Earth;

- assuming production practices and consumer behaviour in harmony with the rights of Mother Earth;

- ensuring the sustainable use of Mother Earth's components; and

- reporting any act that violates the rights of Mother Earth, living systems, and/or their components. ${ }^{78}$

Compared with the duties of the state, these non-state duties are far-reaching and more clearly oriented towards ecocentrism. As we argue below, this disparity gives rise to some concerns.

\subsection{The Framework Law of Mother Earth and Integral Development for Living Well}

In 2012, the Bolivian Legislative Assembly adopted the Framework Law ${ }^{79}$ in an attempt to reaffirm and implement the goals formulated in the Bolivian Constitution and the Law of the Rights of Mother Earth. ${ }^{80}$ Originally the Framework Law was to be the

77 Ibid., Art. 8.

78 Ibid., Art. 9.

79 N. 14 above. As no English version is available, all references to the Framework Law are the authors' translations. 
second and final step of a legislative process based on the Unity Pact Draft Law. However, as noted above, the Unity Pact Draft Law was set aside, and the Assembly instead adopted the Framework Law. ${ }^{81}$ This Law was created to operationalize the Law of the Rights of Mother Earth. An overview is offered below.

Article 1 states that the Framework Law aims to establish the vision, fundamentals and objectives of integral development in harmony with Mother Earth for Vivir Bien, guaranteeing the continued capacity of Mother Earth to regenerate natural systems, and recapturing and strengthening ancestral knowledge and practices within a framework of rights and obligations. The Framework Law pursues four goals: (i) to determine the principles guiding access to the components and living systems of Mother Earth; (ii) to establish the objectives of integral development; (iii) to guide specific legislation, policies, regulations, strategies, plans and programmes to achieve Vivir Bien through integral development; and (iv) to define the institutional framework for promoting and implementing integral development. ${ }^{82}$

The Framework Law also affirms certain core principles governing its implementation. ${ }^{83}$ For example, it highlights complementarity between the rights of people on the one hand and the rights of Mother Earth on the other: 'no right can be realized without the others, nor be placed above other rights, implying the interdependency and mutual support of [all] ... rights'. ${ }^{84}$ In another effort to eliminate hierarchies between rights, the principle of 'water for life' states that the use of and access to water sources should satisfy both the conservation of Mother Earth's components and living systems and the satisfaction of human needs. ${ }^{85}$

In addition to such well-known principles as polluter pays, precaution, and prevention, ${ }^{86}$ the Framework Law incorporates others, such as the principle of restoration of Mother Earth, which stresses restorative obligations when the Earth system is affected by human activities. ${ }^{87}$ However, restoration was established as a right in the Law of the Rights of Mother Earth, ${ }^{88}$ rather than as a principle as is the case in the Framework Law. Furthermore, according to the principle of 'complementarity and equilibrium', the state should promote equilibrium among all living beings for Vivir Bien. ${ }^{89}$ In addition, the principle of solidarity prioritizes the rights of vulnerable low-income people when promoting actions related to integral development. ${ }^{90}$ While commendable, this principle erodes the pre-eminence of the rights of Mother Earth by referring to solidarity between human beings only and not

80 U.K. Heise, Imagining Extinction: The Cultural Meanings of Endangered Species (The University of Chicago Press 2016), p. 119.

81 Servendi, n. 58 above.

82 Framework Law 300, n. 14 above, Art. 3.

83 Ibid., Art. 4.

84 Ibid., Art. 4.1.

85 Ibid., Art. 4.10.

86 Ibid., Arts 4.4, 4.7 and 4.8.

87 Ibid., Art. 4.5.

88 Law 071, n. 13 above, Art. 7.6.

89 Framework Law 300, n. 14 above, Art. 4.16.

90 Ibid., Art. 4.11. 
also to solidarity between humans and non-human living beings, which collectively make up the community of all life on Earth.

Beyond these broad principles, Article 5.1 of the Framework Law includes the same definition of Mother Earth as does the Law of the Rights of Mother Earth and, like that Law, it specifies that Mother Earth is the home that nurtures, sustains, and reproduces all living beings. Furthermore, the Framework Law reaffirms the rights established in the Law of the Rights of Mother Earth and in similar terms it calls for the creation of an Office of Mother Earth, ${ }^{91}$ although it does not provide specific procedures for its organization. It merely states that the Office has standing to bring proceedings before administrative and/or judicial authorities to enforce the rights of Mother Earth and should be part of the Plurinational Council for Living Well in Harmony and Balance with Mother Earth (Consejo Plurinacional para Vivir Bien en Armonía y Equilibrio con la Madre Tierra), a participatory body which, like the Office of Mother Earth, has not been created at the time of this writing. ${ }^{92}$

The Framework Law specifies that an infringement of the rights of Mother Earth constitutes an infringement of the collective and individual rights of the people. ${ }^{93}$ It envisions individual and collective responsibility for reporting rights violations to administrative or judicial authorities, but it provides a narrow locus standi before the Office of Mother Earth, reserved only for public authorities and for individuals or groups directly affected by such violations. ${ }^{94}$ The narrow locus standi provisions are potentially in conflict with the much wider actio popularis procedure established in the Bolivian Constitution to defend and enforce environmental rights. ${ }^{95}$ According to the Framework Law, administrative sanctions and civil liability can arise from infringement of the rights of Mother Earth, including joint and several liability where appropriate. ${ }^{96}$ In addition, the Framework Law refers to criminal liability arising from an offence against the rights of Mother Earth, although it provides no further details in this respect. ${ }^{97}$ Notably, the Law states that there is no statute of limitations for the prosecution of offences against the rights of Mother Earth. ${ }^{98}$

Vivir Bien (Sumaj Kamaña, Sumaj Kausay or Yaiko Kavi Päve) is defined in the Framework Law as an alternative cultural developmental vision to capitalism and modernity that emerges from the worldviews of indigenous, native, and peasant nations. ${ }^{99}$ Essentially, Vivir Bien means 'living in complementarity, in harmony and

91 Ibid., Art. 39.3.

92 Ibid., Arts 39.3 and 52.VI.

93 Ibid., Art. 38.

94 Ibid., Art. 39.

95 Constitution of the Plurinational State of Bolivia, n. 21 above.

96 Framework Law 300, n. 14 above, Arts 41 and 43.

97 Ibid., Art. 44.I.

98 Ibid., Art. 44.II. However, the imprescriptibility of such offences has not been included in the draft of the new Penal Code, which, at the time of writing, is being debated by the Plurinational Legislative Assembly: Camara de Diputados del Estado Plurinacional de Bolivia, 'PL No. 122/2017-2018: Proyecto de Ley: Código del Sistema Penal Boliviano’, available at: http://www.diputados.bo/leyes/pl-n $\%$ C2\%B0-1222017-2018.

99 Framework Law 300, n. 14 above, Art. 5.2. 
in balance with Mother Earth and societies, in equality and solidarity and eliminating the inequalities and mechanisms of control and domination' ${ }^{100}$ According to Article 9 of the Framework Law, the Vivir Bien must be achieved in a way that is complementary to the rights of humans and the rights of Mother Earth, although it stresses that human actions (whether economic, social, ecological or spiritual) could be limited by the regenerative capacity of Mother Earth. It fails to explain how this new understanding of the relationship between people and nature should be achieved in concrete terms.

To balance development on the one hand and the protection of nature on the other, ${ }^{101}$ the Framework Law establishes the notion of 'integral development'. This is defined as the implementation of integrated measures to create and reinforce social, spiritual, and material conditions, capacities, and means aimed at facilitating and strengthening community linkages in order to achieve Vivir Bien in harmony with Mother Earth. ${ }^{102}$ In this view, integral development is not the end result, but the process leading to Vivir Bien. ${ }^{103}$

The Framework Law contains clear contradictory objectives and provisions, which it embodies through the concept of integral development. For example, it legalizes rather than prohibits mining, though it calls for the use of best available technologies during extractive activities in order to reduce their impact. ${ }^{104}$ The Framework Law also places an obligation on the state to create conditions to ensure growth, ${ }^{105}$ which legitimizes and even promotes extractivist activities such as mining. While extractive practices arguably, by their very nature, are always harmful to the environment to the extent that they dislodge the harmony of an ecosystem, it is further surprising (but revealing in light of our analysis below) that the Bolivian legislature saw fit to include provisions that promote mining in this particular Law, which focuses on the protection of Mother Earth, and not in a law on mining or economic development.

The state also has the obligation to promote investment and to create conditions to ensure the equal distribution of Mother Earth's components and the wealth generated by the exploitation of natural resources in order to build a just Bolivian society free from poverty. ${ }^{106}$ There is clearly an inherent tension in the Framework Law between its lofty protection of the rights of Mother Earth on the one hand and, on the other, its far-ranging promotion of integral socio-economic development. The Law is neither specific nor concrete and, like the Law of the Rights of Mother Earth, it is concerned with establishing broad guiding principles. It has been criticized on the grounds that it 'looks more like a declaration of principles than a precise legal instrument, so that the

\footnotetext{
100 Ibid.

101 This was noted by the Vice-President of Bolivia at the promulgation ceremony of the Framework Law: Vicepresidencia del Estado Plurinacional de Bolivia, 'García: Ley de Madre Tierra establece equilibrio entre desarrollo y preservación de naturaleza’, 15 Oct. 2012, available at: https://www.vicepresidencia. gob.bo/Garcia-Ley-de-Madre-Tierra.

102 Framework Law 300, n. 14 above, Art. 5.3.

103 Ibid.

104 Ibid., Art. 15.3.

105 Ibid., Art. 10.1.

106 Ibid., Arts 18 and 19.
} 
possibilities for concrete applications are limited'. ${ }^{107}$ Counter-intuitively, then, the Framework Law may actually strengthen the paradigm of neoliberal development instead of introducing a new form of development that respects the rights of Mother Earth: 'It restores the idea of development, legitimating it in a political norm and placing it as a necessary element for vivir bien ... it minimises vivir bien and robs it of its vocation as a radical break with development and the transcendence of modernity'. 108

\section{A CRITICAL APPRAISAL}

This penultimate section explores some of the shortcomings and contradictions in Bolivian law relating to the rights of Mother Earth and environmental protection more generally.

\subsection{A Window-Dressing Exercise?}

One of the principal benefits of Bolivia's efforts to protect the rights of Mother Earth was not an improvement in environmental quality per se. The much 'softer' consequence was a significant elevation of the popular social and political profile of Bolivia as a global champion (at least on paper) of the rights of Mother Earth; or, in the words of Lalander, its 'ethno-ecologist image'. ${ }^{109}$ This was an opportunity to shape perceptions about the country and to influence the global political discourse on ecocentric approaches to environmental protection. Evo Morales and his government did not waste the opportunity. In 2009, Morales persuaded the United Nations (UN) General Assembly to designate 22 April as the International Day of Mother Earth, recognizing the need to promote the harmonious coexistence of people with the Earth. ${ }^{110}$ In August of the same year, the UN General Assembly declared Morales 'World Hero of Mother Earth'. ${ }^{111}$ Some universities awarded him the degree Doctor Honoris Causa in appreciation of his defence of Mother Earth. ${ }^{112}$ Further, in response to a proposal by Morales, the UN General Assembly incorporated the theme of 'Harmony with Nature' into its broader policy and political agenda. ${ }^{113}$ With the support of the G77 + China, Bolivia's President also promoted the incorporation of important provisions regarding Mother Earth into the outcome document of the

\footnotetext{
107 Gudynas, n. 33 above, p. 25.

108 Ibid., pp. 25-6.

109 Lalander, n. 22 above, p. 465.

110 UNGA Resolution 63/278, 'International Mother Earth Day' (22 Apr. 2009), UN Doc. No. A/RES/63/ 278.

111 UN, 'Remarks of H.E. Miguel D'Escoto Brockmann, President of the United Nations General Assembly, at the Mother Earth Special Event', 22 Apr. 2009, available at: http://www.un.org/esa/ socdev/unpfii/documents/MEDSE_PGA_en.doc.

112 E.g., the Sapienza Università di Roma, Sept. 2015, available at: https://www.noticiasfides.com/nacional/ sociedad/universidad-sapienza-de-italia-otorga-titulo-de-doctor-honoris-causa-a-evo-359063-359013; and the Universidad Nacional Ecológica de Bolivia, Dec. 2015, available at: http://www.comunicacion. gob.bo/?q=20151204/20061.

113 UNGA Resolution 64/196, 'Harmony with Nature’ (21 Dec. 2009), UN Doc. No. A/RES/64/196.
} 
Rio+20 Conference on Sustainable Development, ${ }^{114}$ The Future We Want. ${ }^{115}$ For instance, the document now states:

39. We recognize that planet Earth and its ecosystems are our home and that 'Mother Earth' is a common expression in a number of countries and regions, and we note that some countries recognize the rights of nature in the context of the promotion of sustainable development.

40. We call for holistic and integrated approaches to sustainable development that will guide humanity to live in harmony with nature and lead to efforts to restore the health and integrity of the Earth's ecosystem.

As symbolically important as such recognition is on the international stage especially to the extent that it reveals and brings to the world's attention dramatically different ecocentric rights-based approaches to environmental protection regrettably, the actual protection of the rights of Mother Earth in Bolivia (as in the rest of the world) does not measure up to these widely celebrated achievements. The contradictions are evident between the indigenous peoples' vision of a protected Mother Earth and the philosophy of Vivir Bien on the one hand, and the neoliberal logic of development on the other. At the time of writing, the Bolivian government has neither approved new environmental legislation consistent with the Law of the Rights of Mother Earth and the Framework Law, nor repealed major laws that are inconsistent with those laws; ${ }^{116}$ nor has it established the Office for the Protection of Mother Earth. The creation of this office would arguably have fostered significant progress in promoting compliance with the requirement that the rights of Mother Earth be protected. Arguably, Bolivia's efforts have had greater epistemic, symbolic and political impact outside its borders than within. This raises the suspicion that the Laws relating to the rights of Mother Earth are merely attempts to window-dress ongoing environmental destruction and the exploitation of nature and of indigenous people. Indeed, there seems to be merit in the view that Evo Morales 'seeks to appear "green" even as he proposes major development and extraction projects that will bring severe environmental impacts'. ${ }^{117}$

Relatedly, although Article 16.1 of the Framework Law recognizes the right of indigenous peoples to free, prior, and informed consent, it does not explicitly recognize their right to approve or reject projects that occur in their territories. This is contrary to the UN Declaration on the Rights of Indigenous Peoples, ${ }^{118}$ which Bolivia adopted as national law and which applies in the country by virtue of Articles 256

\footnotetext{
114 Rio de Janeiro (Brazil), 20-22 June 2012, available at: https://www.uncsd2012.org.

115 UNGA Resolution 66/288, 'The Future We Want' (27 July 2012), UN Doc. No. A/RES/66/288. Similar references were included in the UNGA Resolution 70/01, 'Transforming Our World: The 2030 Agenda for Sustainable Development' (25 Sept. 2015), UN Doc. No. A/RES/70/1.

116 Environmental Law 1333 of 1992, adopted prior to the Bolivian Constitution, is still in force and is the legislative framework for industrial activities in Bolivia. This law enunciates anthropocentric modes of environmental protection and has not been adapted to the new rights of Mother Earth paradigm.

117 Margil, n. 10 above, p. 155.

118 UNGA Resolution 61/295, 'UN Declaration on the Rights of Indigenous Peoples' (13 Sept. 2007), UN Doc. No. A/RES/61/295.
} 
and 257 of the Constitution. ${ }^{119}$ In a nutshell, the Framework Law is a wolf in sheep's clothing. Instead of protecting the rights of Mother Earth, as its name suggests it should, it includes provisions that promote the prevailing neoliberal anthropocentric development model followed by Morales' government. It militates against the interests of indigenous peoples and is broadly unsympathetic to the model of pursuing life in harmony with nature, an idea often proclaimed in its text and promoted in public by the Morales government. ${ }^{120}$

\subsection{Constitutional Tensions}

Constitutions require compromises among interested parties. It is unreasonable to expect any constitution to achieve strict ecocentric purity, as it were. Like other constitutions, the Bolivian Constitution contains several provisions regarding the exploitation of natural resources. Difficult tensions often arise between ecocentric and anthropocentric provisions in the Constitution, tensions which we believe are not ultimately conducive to supporting the rights of Mother Earth, and which will be difficult to resolve in practice.

By way of example, the impact of the Constitution's elaborate environmental right is apparently diluted by a provision setting out one of the 'essential purposes and functions of the State', namely:

To promote and guarantee the responsible and planned use of natural resources, and to stimulate their industrialization through the development and strengthening of the productive base in its different dimensions and levels, as well as to preserve the environment for the welfare of present and future generations. ${ }^{121}$

The Constitution also establishes that ' $[\mathrm{t}]$ he State places the highest value on human beings and assures the development through the equitable redistribution of economic surplus in the social policies ... ${ }^{122}$ The elimination of poverty and social and economic exclusion is a noble and crucial goal in itself, especially in a developing country such as Bolivia. However, instead of pursuing ecologically sensitive ways to go about this, the legal framework actively enables the state to promote the industrialization of natural resources as 'a national priority'. ${ }^{123}$ Indeed, the exploitation of natural resources is explicitly defined as one of the purposes and functions of the state. ${ }^{124}$ Activities related to the exploration, exploitation, refining, industrialization, transport and sale of natural resources are therefore characterized in the Bolivian Constitution as matters of necessity and public utility. ${ }^{125}$

Tensions between development and conservation result from normative disputes between ecocentric and anthropocentric constitutional provisions. The Constitution

\footnotetext{
119 Law 3760 of 7 Nov. 2007. Bolivia was the first country in the world to incorporate the Declaration into national legislation.

120 See, e.g., Framework Law 300, n. 14 above, Arts 1, 3, 4, 7, 9 and 10.

121 Constitution of the Plurinational State of Bolivia, n. 21 above, Art. 9(6).

122 Ibid., Art. 306.

123 Ibid., Arts 9.6, 316.6, and 355.

124 Ibid., Arts 11 and 316.3.

125 Ibid., Art. 356.
} 
explicitly rejects any internal hierarchy of norms: 'The classification of the rights established in this Constitution does not determine any hierarchy or superiority of some rights over others'. ${ }^{126}$ All Constitutional rights are on an equal footing and one should not be exercised at the expense of another. Yet, those rights associated with socio-economic development seem to take precedence in practice. For example, despite its lofty Preamble, the Constitution's few provisions on environmental protection pale in comparison with its sprawling Part IV, which provides in significant detail (across 36 articles) for the 'economic structure and organization of the state'. To be sure, included in Part IV is Title II, which deals with 'Environment, Natural Resources, Land and Territory', but the environmental measures contained therein are less focused on environmental protection than they are on regulating the industrialization of environmental resources. This much is evident from the provision that ' $[\mathrm{t}]$ he industrialization and sale of natural resources shall be a priority of the State' ${ }^{127}$ Later provisions on biodiversity conservation in Chapter VII follow a similar approach, sanctioning the exploitation of natural resources with the compromise that 'renewable natural resources shall be exploited in a sustainable way, [while] respecting the characteristics and natural value of each ecosystem'. ${ }^{128}$

Also included in Title II is a lengthy chapter on hydrocarbons, which proclaims:

[Hydrocarbons] are the inalienable and unlimited property of the Bolivian people. The State, on behalf of and in representation of the Bolivian people, is owner of the entire hydrocarbon production of the country and is the only one authorized to sell them. The totality of the income received by the sale of hydrocarbons shall be the property of the State. ${ }^{129}$

The Constitution declares that it is the prerogative and duty of the state to 'promote [the] comprehensive, sustainable and equitable development [of hydrocarbons]'. ${ }^{130}$ The Constitution contains similar provisions on mining and metallurgy in the subsequent chapter, all under the (some would say disingenuous) banner of 'redistributive justice, welfare reforms and the common good'. ${ }^{131}$

One may not expect a country that proclaims itself to have left the colonial, republican and neo-liberal State in the past ${ }^{132}$ to pursue such a comprehensive neoliberal agenda that also seems to conflict with the rights of Mother Earth it seeks to protect through constitutional and statutory measures. However, states such as Bolivia find themselves in a profound dilemma: they must deliver welfare for all, and to do so they often choose to exploit natural resources instead of pursuing less environmentally damaging activities such as eco-tourism or investment in the renewable energy sector. Such an approach ultimately compromises the very rights of nature and of indigenous peoples whom the state seeks to protect. ${ }^{133}$ No practical

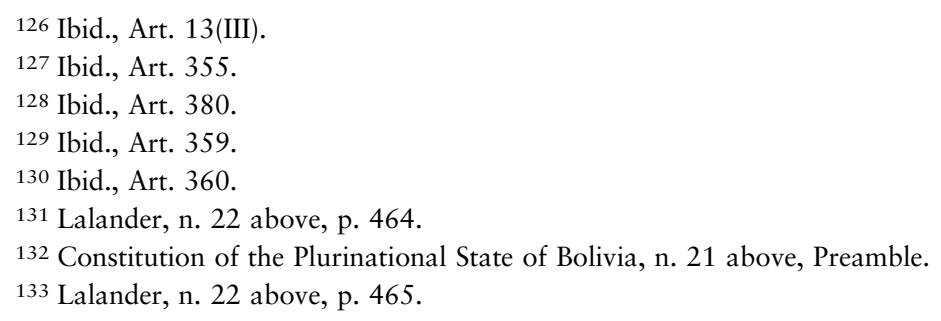


solution to this dilemma is immediately apparent. While it is not unique to Bolivia, it is particularly problematic in that country because of its unique legal framework for the protection of the rights of Mother Earth.

\subsection{Statutory Tensions}

Similar contradictions and inconsistencies also plague the two statutes on the rights of Mother Earth. Both include an ecocentric counter-narrative, while the Framework Law at the same time reflects the neoliberal extractivist agenda of Morales' government. ${ }^{134}$ The Framework Law presented integral development as an alternative to modern development, yet ultimately did not unseat the idea that development and progress are based on the exploitation of natural resources. Despite the Constitution's clear pronouncement on the non-hierarchical order of rights, the Framework Law places the fundamental rights of persons and the public interest in a just and equitable society without poverty above Mother Earth and the protection of her rights. In accordance with the notion of Vivir Bien, both objectives should go hand in hand; neither should be prioritized over the other. $^{135}$

Tensions between national welfare policies based on extractivism and the rights of Mother Earth are also evident in government efforts to expand the extractive industry. In May 2014, the government enacted a new Law on Mining and Metallurgy (Ley 535 de Minería y Metalurgia), ${ }^{136}$ which has been described as an open assault on Mother Earth. ${ }^{137}$ This Law imposes several limitations on the rights of Mother Earth: for example, it authorizes mining activities in protected natural areas, ${ }^{138}$ and sustains pre-existing mining rights, concessions, and contracts. This allows the mining industry to control the use of water resources, which can be used by rights holders without the imposition of additional licence requirements related to resource protection. ${ }^{139}$ Thus, the Law not only represents a threat to undeveloped areas, but also enables mining companies to use water resources without regulatory controls. It also increases the risk of over-exploitation of water resources, with predictably dire adverse impacts on local communities and the environment. ${ }^{140}$ As a case in point, the over-exploitation of water resources in the Department of Oruro (in western Bolivia), as a result of mining, is considered to have caused the

134 Hindery, n. 47 above, p. 217.

135 See, e.g., Framework Law 300, n. 14 above, Arts 7, 10.1 and 18.

136 Law 535 on Mining and Metallurgy, 28 May 2014.

137 M. Gandarillas, 'Bolivia: La década dorada del extractivismo', in M. Gandarillas (ed.), Extractivismo: Nuevos contextos de dominación y resistencias (CEBID, 2014), pp. 103-32, at 130.

${ }^{138}$ Law 535, n. 136 above, Art. 220. The Law requires that such activities comply with environmental and related regulations, and must not affect the achievement of the objective of protecting the environment. However, the environmental legislation (Law 1333, n. 116 above) was adopted prior to the Bolivian Constitution and the laws related to the rights of Mother Earth, and has not been reformed to comply fully with the new protective paradigm.

139 Ibid., Art. 13 IV.

140 In 2014, 1,848 rivers and 39 lakes in Bolivia overlapped with mining areas: O. Campanini, Agua y minería en Bolivia (CEBID, 2014), p. 21, available at: http://www.cedib.org/publicaciones/agua-ymineria-en-bolivia-3ra-edicion. 
disappearance of Lake Poopo, the second largest lake in Bolivia after Lake Titicaca. $^{141}$

By promoting both the defence of Mother Earth and the model of integral development based on the exploitation of natural resources, the Framework Law, bolstered as it now is by new powerful mining laws, 'allows the endorsement of the extractivist model under the Mother Earth discourse'. ${ }^{142}$ It effectively becomes a statutory device that legalizes extractivism as a way of achieving the Vivir Bien, instead of pursuing alternative ways to generate income, such as eco-tourism. ${ }^{143}$ Rather than situate the protection of Mother Earth as the first and foremost priority as one would expect it to do, the Law authorizes the continuation of extractivism in response to economic and social demands. To this end, the radical indigenous ecological essence of Vivir Bien is displaced by the Western anthropocentric logic of modern neoliberal development. This not only serves to highlight tensions between the rights of Mother Earth and provisions that enable ecological destructive practices, but also tensions between those indigenous Earth-centred worldviews discussed above and the evidently far stronger Western paradigm of neoliberal development that is actively being opposed by indigenous Bolivians.

\subsection{Regression on Environmental Standards}

In an apparent blow to the rights of Mother Earth, the Bolivian government has sought to ease environmental standards to allow for oil and gas exploration in protected areas populated by indigenous peoples. For example, Supreme Decree 2366, enacted in May 2015, legalizes exploratory drilling in more than 60 of Bolivia's protected areas and in its 22 national parks. ${ }^{144}$ Such operations are defended on the premise that they will contribute to the country's redistributive socio-economic development and will help to reduce poverty and to improve social welfare. ${ }^{145}$ However, according to some government critics, this law chronicles a 'death foretold of Bolivia's protected areas' as well as proof of the environmental disasters that Morales' government is causing 'in the name of Mother Earth'. ${ }^{146}$

Since the promulgation of the Supreme Decree, the government, through several subsequent executive decisions, has extended the so-called 'oil border' (which delineates areas where oil exploration may take place) into the Amazonian and Gran Chaco regions of the country. ${ }^{147}$ Several protected areas are located in these regions,

\footnotetext{
141 B.C. Howard, 'Bolivia's Second Largest Lake Has Dried Out: Can It Be Saved?', National Geographic, 21 Jan. 2016, available at: http://news.nationalgeographic.com/2016/01/160121-lake-poopo-boliviadried-out-el-nino-climate-change-water.

142 Prada Alcoreza, n. 55 above.

143 Ibid.

144 Supreme Decree 2366, 20 May 2015, Art. 2.I. At least 11 of the 22 national parks could be affected by the oil activity legitimized by this Decree: B. Layme, 'Bolivia se sumó a la corriente de explotar áreas protegidas', Página Siete, 24 June 2015, available at: http://www.paginasiete.bo/nacional/2015/6/24/ bolivia-sumo-corriente-explotar-areas-protegidas-60974.html.

145 Supreme Decree 2366, ibid., Art. 1.

146 D. Hill, 'Bolivia Opens up National Parks to Oil and Gas Firms', The Guardian, 5 June 2015, available at: http://www.theguardian.com/environment/andes-to-the-amazon/2015/jun/05/bolivia-national-parks-oil-gas.

147 Supreme Decree 2549, 14 Oct. 2015.
} 
and many of them are already being adversely affected by oil exploration and extraction activities. ${ }^{148}$ This represents a direct threat both to the environment and to the indigenous people in these areas. ${ }^{149}$ Moreover, the government plans to explore shale gas deposits by means of hydraulic fracturing in several parts of Bolivia. ${ }^{150}$ Collectively, this suggests that the exploitation of natural resources within the state's national borders has become a priority for the government, which announced in 2016 that state and private investment in the hydrocarbon sector will substantially increase, reaching USD 14.6 billion by 2020. ${ }^{151}$ As critics of Morales' government note, this demonstrates the dissonance between the government's rhetoric and actual practice regarding the protection of the rights of Mother Earth, as well as clear regression on constitutional and statutory environmental standards. ${ }^{152}$

\subsection{Natural Resource Wars and Oppression of Indigenous People}

The tensions described above are clearly reflected in a conflict that has been described as 'the most emblematic case of ethno-ecologist resistance against extractive developmentalist policies ${ }^{153}$ in Bolivia. In 2011, the government initiated the construction of a highway across the Isiboro Sécure National Park and Indigenous Territory (Territorio Indígena y Parque Nacional Isiboro Sécure (TIPNIS)), an area particularly rich in flora and fauna. ${ }^{154}$ The project started without consultation with the indigenous peoples who live in the park, in clear breach of the law and the Bolivian Constitution. ${ }^{155}$ The existence of the highway, the accompanying promotion of oil exploration, the expansion of coca plantations, and deforestation are expected not only to affect the rich biodiversity of the region, but also to threaten the traditional lifestyles and existence of the indigenous people living in the national park.

The mega-project was justified by Morales' government as a crucial step towards ensuring national integration, development, and social welfare. ${ }^{156}$ Public opposition

148 Since 2012, the oil border has been extended from 24 to more than 31 million hectares: R. Guidi, 'Oil Exploration in Bolivia's Amazon Region Goes on Overdrive', Mongabay, 25 Feb. 2016, available at: https://news.mongabay.com/2016/02/oil-exploration-in-bolivias-amazon-region-goes-on-overdrive.

149 See, e.g., 'Comunarios marcharon cuatro días en defensa de Tariquía', Página Siete, 28 Apr. 2017, available at: http://www.paginasiete.bo/sociedad/2017/4/28/comunarios-marcharon-cuatro-diasdefensa-tariquia-135887.html.

150 D. Hill, 'Is Bolivia Going to Frack Mother Earth?', The Guardian, 24 Feb. 2015, available at: http://www.theguardian.com/environment/andes-to-the-amazon/2015/feb/23/bolivia-frack-mother-earth.

151 El Periódico de la Energía, 'Bolivia anuncia la inversión de 13.200 millones de euros en hidrocarburos hasta 2020', 12 July 2016, available at: http://elperiodicodelaenergia.com/bolivia-anuncia-inversion-de13-200-millones-en-hidrocarburos-hasta-2020.

152 Hill, n. 150 above.

153 Lalander, n. 22 above, p. 466.

154 See further J.A. McNeish, 'Extraction, Protest and Indigeneity in Bolivia: The TIPNIS Effect' (2013) 8(2) Latin American and Caribbean Ethnic Studies, pp. 221-42; A.C. Delgado, 'The TIPNIS Conflict in Bolivia' (2017) 39(2) Contexto Internacional, pp. 373-91.

155 Constitution of the Plurinational State of Bolivia, n. 21 above, Arts 11.II.1, 30.II. 15, 352 and 403.

156 F. Chávez, 'Bolivia: Carretera del TIPNIS entre desarrollismo y Buen Vivir', IPS Agencia de Noticias, 23 Aug. 2011, available at: http://www.ipsnoticias.net/2011/08/bolivia-carretera-del-tipnis-entredesarrollismo-y-buen-vivir. 
mounted and, in August 2011, indigenous people and environmental activists organized marches that took place over two months. During that period the protesters also demonstrated in La Paz (Bolivia), asserting their right to be consulted on the project and its impacts. This protest, one of the largest and most significant indigenous resistances in the history of Bolivia, was harshly suppressed. ${ }^{157}$

The government eventually gave in to the demands of the protesters and, in October 2011, passed a law declaring the TIPNIS as a pristine area, thus halting the construction of the highway. ${ }^{158}$ However, counter-pressure by the coca producers in the TIPNIS area, who supported the project, led to another reversal in 2012. A new law required a broad public consultation process to take place with the indigenous inhabitants of the TIPNIS concerning its protection and the construction of the highway. ${ }^{159}$ According to the government, $82 \%$ of the communities consulted rejected the pristine status of the TIPNIS, while $80 \%$ supported the construction of the highway. ${ }^{160}$ However, it was alleged subsequently that the consultation was conducted in the absence of an environmental impact study and regulations concerning consultation processes in the country. ${ }^{161} \mathrm{~A}$ later evaluation determined that the consultation process had been subject to a series of irregularities. $^{162}$

Following these controversies, there were signs in 2014 that the project would be suspended. The Bolivian Vice-President acknowledged that the highway project needed to be postponed as a result of the government's failures during the consultation process, among other reasons. ${ }^{163}$ Nevertheless, in June 2015 Morales announced that the construction of the highway would go ahead. ${ }^{164}$ The government, in March 2017, published a draft law aimed at allowing the construction of a socalled 'green highway' through the TIPNIS. ${ }^{165}$ Indigenous people living in the park

157 E. Achtenberg, 'Police Attack on TIPNIS Marchers Roils Bolivia', 28 June 2011, NACLA Blog, available at: http://nacla.org/blog/2011/9/28/police-attack-tipnis-marchers-roils-bolivia.

${ }^{158}$ Law 180 on the Protection of the Isiboro Sécure National Park and Indigenous Territory (Ley 180 de Protección del Territorio Indígena y Parque Nacional Isiboro Sécure - TIPNIS), 24 Oct. 2011.

159 Law 222 on Consultation on the Isiboro Sécure National Park and Indigenous Territory (Ley 222 de Consulta a los Pueblos Indígenas del Territorio Indígena y Parque Nacional Isiboro Sécure - TIPNIS), 7 Feb. 2012, Arts 1 and 4.

160 Tribunal Supremo Electoral de Bolivia, Informe de Observación y acompañamiento de la Consulta Previa, Libre e informada a los pueblos indígenas del Territorio Indígena y Parque Nacional Isiboro Sécure (TIPNIS) (Servicio Intercultural de Fortalecimiento Democrático, 2013), available at: http://www.oep.org.bo/images/PROCESOS_ELECTORALES/consulta_tipnis/informe_tipnis/informe_ tipnis_2013.pdf.

161 Asamblea Permanente de Derechos Humanos de Bolivia (APDHB) and Federación Internacional de Derechos Humanos (FIDH), Bolivia: Informe de verificación de la consulta realizada en el Territorio Indígena Parque National Isiboro-Sécure, Apr. 2013, p. 6, available at: http://www.cedib.org/wpcontent/uploads/2013/05/informeFIDHtipnis1.pdf.

162 Ibid., p. 21.

163 'El Vicepresidente descarta carretera por el TIPNIS', Página Siete, 4 Jan. 2014, available at: htttp://www.paginasiete.bo/nacional/2014/1/4/vicepresidente-descarta-carretera-tipnis-10441.html.

164 R. Ariñez, 'Evo anuncia que la carretera que atraviesa el TIPNIS “se realiza”, La Razón, 5 June 2015 , available at: http://www.la-razon.com/nacional/Evo-carretera-atraviesa-TIPNIS-realiza_0_22839716 14.html.

165 K. Carrillo, 'Indígenas del TIPNIS, nuevamente en alerta', Los Tiempos, 4 Mar. 2017, available at: http://www.lostiempos.com/actualidad/economia/20170304/indigenas-del-tipnis-nuevamente-alerta. 
strongly objected to the draft legislation, alleging that it was an attack on their rights as well as a violation of the Constitution and international law. ${ }^{166}$ Finally, in August 2017, the government enacted the Law on Protection, Integral and Sustainable Development of the Isiboro Sécure National Park and Indigenous Territory (TIPNIS), ${ }^{167}$ which repealed the Isiboro Sécure National Park and Indigenous Territory TIPNIS Protection Law of 2011, thus allowing the construction of the highway and other transportation infrastructure, as well as the exploitation of natural resources within the national park and those located in indigenous territory. ${ }^{168}$ This effort paid little regard to Bolivian laws aimed at protecting the rights of Mother Earth.

\section{CONCLUSION}

Bolivia's effort to legally protect the rights of Mother Earth is a significant milestone. The country's Constitution, its Law of the Rights of Mother Earth, and the Framework Law are concrete examples in which the law attempts to turn away (if not always successfully) from anthropocentric hierarchies while embracing care for Mother Earth as an ethical obligation of ecological stewardship. On paper at least, the legal protection of the rights of non-human entities provides an opportunity for society to redirect its behaviour away from growth-without-limits paradigms towards an altogether more careful ecological approach.

Often, however, such juridical transformations are only the first step towards bringing about deeper change. With the rights of nature debate now increasingly becoming an issue of global interest - especially insofar as concrete attempts by some countries to constitutionalize and legislate such rights offer examples of transnational comparative legal borrowing - there are important general insights that present themselves from the Bolivian experience. In addition to what we have concluded throughout this article, one such insight is that law has limitations, and one must remain realistic about its potential to counter deeply vested political, social and economic interests. Law will always remain merely one ingredient (albeit a powerful one) in the social institutional regulatory toolbox. However, where it does provide for radical formulations (such as rights of nature), it prompts us to start having conversations about ways in which to accommodate such novel juridical constructs in our social, economic, religious, legal and political structures, including ways to implement them and ways of resolving the many normative and practical contradictions that are likely to arise when the interests that the rights of nature seek to protect collide with those championed by the neoliberal developmental agenda. The ultimate test for law in relation to protecting the rights of Mother Earth

166 K. Carrillo, '64 comunidades del TIPNIS rechazan proyecto de ley', Los Tiempos, 7 Mar. 2017, available at: http://www.lostiempos.com/actualidad/economia/20170307/64-comunidades-del-tipnisrechazan-proyecto-ley.

167 Law 969 on Protection, Integral and Sustainable Development of the Indigenous Territory Isiboro Sécure National Park TIPNIS (Ley 969 de Protección, Desarrollo Integral y Sustentable del Territotio Indigena Parque Nacional Isiboro Sécure - TIPNIS), 13 Aug. 2017.

168 Ibid., Arts 8 and 9. 
accordingly is not the extent to which it is actually able to return Bolivia (and the rest of the world) to an Edenesque state in the near future, but the extent to which it is able to continuously challenge, over a period of time, those deeply vested neoliberal economic, political and social interests that threaten Earth system integrity.

A second important insight, we believe, is that much can be learned from indigenous worldviews, especially to the extent that they provide alternative ways of juridically framing Earth system care. The key challenge in this respect would be to reconcile as far as possible such radical worldviews with the prevailing, more conventional Western, often Eurocentric and predominantly anthropocentric, visions of law that form the basis of most legal systems the world over. We would need to open ourselves as lawyers, politicians and academics, among many other role players, to these alternative, potentially progressive, and possibly more effective juridical framings that focus on preserving Earth system integrity. 